Research Perspective

\title{
Tune the channel: TRPM8 targeting in prostate cancer
}

\author{
Alessandro Alaimo ${ }^{1}$, Dario De Felice ${ }^{1}$, Sacha Genovesi ${ }^{1}$, Marco Lorenzoni ${ }^{1}$ and \\ Andrea Lunardi ${ }^{1}$ \\ ${ }^{1}$ Department of Cellular, Computational and Integrative Biology (CIBIO), University of Trento, Trento 38123, Italy \\ Correspondence to: Alessandro Alaimo, email: alessandro.alaimo@unitn.it \\ Andrea Lunardi, email: andrea.lunardi@unitn.it \\ Keywords: prostate cancer; TRPM8; precision oncology; cancer translational research \\ Received: June 09, $2021 \quad$ Accepted: September 06, $2021 \quad$ Published: September 10, 2021
}

Copyright: ( 2021 Alaimo et al. This is an open access article distributed under the terms of the Creative Commons Attribution License (CC BY 3.0), which permits unrestricted use, distribution, and reproduction in any medium, provided the original author and source are credited.

\section{ABSTRACT}

The therapeutic landscape of cancer treatments is quickly evolving thanks to the advent of precision oncology. Discovery of novel druggable targets and more reliable biomarkers is a primary objective towards personalized strategies of cancer treatment. Highly expressed in the prostate epithelium within the human body, Transient Receptor Potential subfamily M member 8 (TRPM8) levels rise in primary and hormone naïve metastatic prostate cancer ( $\mathrm{PCa}$ ) lesions, which makes this channel an interesting prototype of molecular target. Recently, by combining a multidisciplinary approach to an in vitro genetic platform, we demonstrated that the combination of potent TRPM8 agonists with $\mathrm{X}$-rays induces a massive apoptotic response in radioresistant pre-malignant and malignant models of primary prostate lesions. As well, TRPM8 activation enhances the efficacy of docetaxel or enzalutamide in eradicating hormone naïve metastatic PCa cells. Overall, our findings provide a solid rationale for pursuing the pre-clinical and clinical study of TRPM8 as a valuable target for future approaches of precise oncology in $\mathrm{PCa}$.

\section{INTRODUCTION}

Prostate Cancer (PCa) is the most commonly diagnosed non-cutaneous cancer in men in the Occident [1]. Despite significant progresses in diagnosis and treatment, PCa remains a primary cause of cancer-related death in both North America and Europe [2]. Patients diagnosed with non-metastatic PCa are highly treatable through surgery or radiotherapy [3]. Contrarywise, patients with high-risk/locally advanced PCa (stage III/ IV) account for approximatively $15 \%$ of all new cases and have a high probability of tumor recurrence following treatment and dying from the disease [4]. For these subjects - depending on physical and clinical parameters such as life expectancy, patient fitness, Gleason score and PSA levels - the therapeutic protocol foresees radical prostatectomy followed by adjuvant radiotherapy, or radiotherapy coupled with adjuvant systemic chemo/ hormonal treatments [4, 5]. Unfortunately, high-risk/ locally advanced PCa often progresses to the metastatic stage of the disease and, after few years of androgen deprivation therapy, gives rise to the more aggressive form of PCa known as castration resistant metastatic condition, which is uncurable [6].

In the recent years, the radical expansion of targeted therapies and precision medicine approaches has significantly improved the overall survival of patients affected by different types of liquid and solid tumors. Unfortunately, these strategies are still far from being applicable to $\mathrm{PCa}[7,8]$. More than ever, the oncology research has the office to identify and characterize molecular targets of clinical relevance. The prevalent expression of molecular targets in cancer cells respect to normal tissues, the druggability, and, finally, the efficacy in killing tumor cells, are all main factors shortening the list of potential valuable candidates. In that regard, ion channels deserve special attention as potential therapeutic targets due to their crucial role in cellular homeostasis and tumorigenesis [9].

Among the growing list of ion channels expressed in normal and tumor prostate epithelial cells, Transient Receptor Potential Melastatin 8 (TRPM8) stands out as one of the most promising clinical targets for $\mathrm{PCa}$ treatment [10-12]. Initially identified as a new prostate- 
specific gene [13], this $\mathrm{Ca}^{2+}$-permeable, nonselective cation channel is, along with TRPA1, the primary cold receptor involved in thermosensation in humans. TRPM8 exhibits multiple gating mechanisms, being activated by painless cool or cold temperatures, and chemical ligands such as menthol [10, 14-16]. TRPM8 expression in humans is limited to cold-sensitive sensory neurons and few epithelial tissues, with prostate luminal cells showing the highest levels $[13,17-19]$. Interestingly, TRPM8 is overexpressed in primary and hormone naïve metastatic PCa [13, 17, 20-22], which leads to an increased amount of functional channels at the plasma membrane of luminal epithelial cells [21]. On the other hand, the expression levels of this channel is frequently reduced in metastatic castration resistant PCa [13, 17, 20, 22]. Even though the role of TRPM8 in prostate tumorigenesis has been investigated by different groups it remains questioned and controversial [12, 23].

Our in-silico analysis of large RNAseq and microarray datasets highlights a substantial inter-tumor heterogeneity of TRPM8 mRNA levels in PCa samples with the full length mRNA generally more abundant compared to its shorter isoforms [22, 24]. Accordingly, immunohistochemistry analysis confirms a heterogeneous distribution of TRPM8 protein amount across human PCa samples with very high TRPM8 staining frequently associated with advanced stage (III/IV) of the disease. Of note, matched primary $\mathrm{PCa}$ and hormone naïve metastatic samples derived from the same patient score very similar for TRPM8 immunostaining [22, 24].

Historically, the effectiveness of targeted therapies has often been determined by the expression level of the selected targets in cancer cells (e.g., EGFR, HER2, PDL1) $[25,26]$. In line with this very general concept, different channel agonists (Icilin, Menthol, WS-12, D-3263) [27-30] triggered intense calcium currents and massive apoptotic response in immortalized prostate cells (RWPE1) that were genetically modified to slightly increase the amount of TRPM8 expression. RWPE-1 cells expressing endogenous levels of the channel were completely refractory to the treatment with TRPM8 agonists. To test TRPM8 targeting in genetic models of pre-malignant and malignant prostate lesions, RWPE-1 characterized by endogenous or increased amount of TRPM8 were further manipulated to express, under doxycycline control, ERG alone [31-33], or ERG plus PTEN shRNAs (ERG/ PTEN-KD) [33, 34]. Severe apoptotic cell death triggered by potent channel agonists in cells expressing increased amount of TRPM8 was completely turned-off in both ERG and ERG/PTEN-KD genetic models, thus suggesting a direct role of ERG in the establishment of a pro-survival cellular program intercepting TRPM8-dependent $\mathrm{Ca}^{2+}$ cytotoxicity [22].

New investigational drugs are often tested in two-arm clinical trials to evaluate their efficacy in improving standard-of-care treatments. Taking advantage of our genetic platform, both pre-malignant (ERG) and malignant (ERG/PTEN-KD) models of primary organ confined lesions characterized by endogenous or overexpressed amount of TRPM8 were enrolled in a pre-clinical trial testing the efficacy of combining the potent channel agonist WS-12 with X-rays. Noteworthy, combination of WS-12 with a sub-lethal dose of X-rays overcame single treatments resistance and induced a diffuse apoptotic response in both ERG and ERG/ PTEN-KD models characterized by slight TRPM8 overexpression [22].

As previously discussed, the clinical protocol for high-risk/locally advanced PCa patients contemplates adjuvant chemo/hormonal treatments following radiotherapy for primary tumors [35]. Adjuvant therapies aim at eradicating residual disease, which may consist in either local tissues invasion by proximity or in micrometastatic lesions spread in the body, commonly in lymph nodes. The hormone sensitive lymph node derived metastatic prostate cancer cell line $\mathrm{LNCaP}_{\mathrm{FGC}}$ were choose as the best proxy to study the possible impact of TRPM8 agonists on either enzalutamide or docetaxel efficacy. $\mathrm{LNCaP}_{\mathrm{FGC}}$ cells were minimally affected by WS-12, docetaxel or enzalutamide when used as single agents. In contrast, combination of WS-12 with either docetaxel or enzalutamide triggers a mild apoptotic cell death response in $\mathrm{LNCaP}_{\mathrm{FGC}}$ cells expressing endogenous levels of TRPM8 which significantly rise to more than $50 \%$ of cells in genetically modified $\mathrm{LNCaP}_{\mathrm{FGC}}$ slightly overexpressing the channel [22].

In conclusion, the greater expression of TRPM8 in primary and hormone naive metastatic $\mathrm{PCa}$, the large number of specific agonists [30], recent advances in the use of nanocarriers [36-38] and small molecules to deliver pharmacological compounds [39, 40], and, finally, the possibility to identify PCa patients who could benefit from the administration of TRPM8 agonists in combination with standard-of-care treatments, makes TRPM8 an extremely attractive target for developing more effective clinical protocols based on personalized $\mathrm{PCa}$ treatments.

\section{ACKNOWLEDGMENTS AND FUNDING}

This work has been supported by the Giovanni Armenise-Harvard Foundation Career Development Award, the Italian Ministry of Education, University and Research (MIUR PRIN 2017) and Lega Italiana Lotta ai Tumori (LILT-Bolzano) granted to A.L. A.A was funded by a postdoctoral fellowship from the Fondazione Umberto Veronesi and by Starting Grants Young Researchers 2019 from the University of Trento. D.DF obtained a PhD fellowship from the University of Trento.

\section{CONFLICTS OF INTEREST}

Authors have no conflicts of interest to declare. 


\section{REFERENCES}

1. Ferlay J, Soerjomataram I, Dikshit R, Eser S, Mathers C, Rebelo M, Parkin DM, Forman D, Bray F. Cancer incidence and mortality worldwide: Sources, methods and major patterns in GLOBOCAN 2012. Int J Cancer. 2015; 136:E359-86. https://doi.org/10.1002/ijc.29210. PMID:25220842

2. Siegel RL, Miller KD, Fuchs HE, Jemal A. Cancer Statistics, 2021. CA Cancer J Clin. 2021; 71:7-33. https:// doi.org/10.3322/caac.21654. PMID:33433946

3. Kibel AS. Treat now or later: the dilemma of postoperative radiotherapy. Eur Urol. 2012; 61:452-54. https://doi. org/10.1016/j.eururo.2011.11.044. PMID:22176781

4. Khauli R, Ferrigno R, Guimarães G, Bulbulan M, Uson Junior PLS, Salvajoli B, Palhares DMF, Racy D, Gil E, de Arruda FF, Lemos GC, Carvalhal GF, de Carvalho IT, et al. Treatment of Localized and Locally Advanced, HighRisk Prostate Cancer: A Report From the First Prostate Cancer Consensus Conference for Developing Countries. JCO Glob Oncol. 2021; 7:530-37. https://doi.org/10.1200/ go.20.00421. PMID:33856890

5. Hamdy FC, Donovan JL, Lane JA, Mason M, Metcalfe C, Holding P, Davis M, Peters TJ, Turner EL, Martin RM, Oxley J, Robinson M, Staffurth J, et al. 10-Year Outcomes after Monitoring, Surgery, or Radiotherapy for Localized Prostate Cancer. N Engl J Med. 2016; 375:1415-24. https:// doi.org/10.1056/NEJMoa1606220. PMID:27626136

6. Moris L, Cumberbatch MG, Van den Broeck T, Gandaglia G, Fossati N, Kelly B, Pal R, Briers E, Cornford P, De Santis M, Fanti S, Gillessen S, Grummet JP, et al. Benefits and Risks of Primary Treatments for High-risk Localized and Locally Advanced Prostate Cancer: An International Multidisciplinary Systematic Review. Eur Urol. 2020; 77:614-27. https://doi.org/10.1016/j.eururo.2020.01.033. PMID:32146018

7. Malik A, Srinivasan S, Batra J. A New Era of Prostate Cancer Precision Medicine. Front Oncol. 2019; 9:1263. https://doi.org/10.3389/fonc.2019.01263. PMID:31850193

8. Attard G, Beltran H. Prioritizing precision medicine for prostate cancer. Ann Oncol. 2015; 26:1041-42. https://doi. org/10.1093/annonc/mdv179. PMID:25862438

9. Prevarskaya N, Skryma R, Shuba Y. Ion Channels in Cancer: Are Cancer Hallmarks Oncochannelopathies? Physiol Rev. 2018; 98:559-621. https://doi.org/10.1152/ physrev.00044.2016. PMID:29412049

10. Knowlton W, McKemy D. TRPM8: from cold to cancer, peppermint to pain. Curr Pharm Biotechnol. 2011; 12:68-77. https://doi.org/10.2174/138920111793937961. PMID:20932257

11. Mckemy DD. Therapeutic potential of TRPM8 modulators. Open Drug Discov J. 2010; 2:81-88.

12. Noyer L, Grolez GP, Prevarskaya N, Gkika D, Lemonnier L. TRPM8 and prostate: a cold case? Pflugers Arch. 2018;
470:1419-29. https://doi.org/10.1007/s00424-018-2169-1. PMID:29926226

13. Tsavaler L, Shapero MH, Morkowski S, Laus R. Trp-p8, a novel prostate-specific gene, is up-regulated in prostate cancer and other malignancies and shares high homology with transient receptor potential calcium channel proteins. Cancer Res. 2001; 61:3760-69. PMID:11325849

14. Peier AM, Moqrich A, Hergarden AC, Reeve AJ, Andersson DA, Story GM, Earley TJ, Dragoni I, McIntyre P, Bevan S, Patapoutian A. A TRP channel that senses cold stimuli and menthol. Cell. 2002; 108:705-15. https://doi.org/10.1016/ s0092-8674(02)00652-9. PMID: 11893340

15. McKemy DD, Neuhausser WM, Julius D. Identification of a cold receptor reveals a general role for TRP channels in thermosensation. Nature. 2002; 416:52-58. https://doi. org/10.1038/nature719. PMID:11882888

16. Señarís R, Ordás P, Reimúndez A, Viana F. Mammalian cold TRP channels: impact on thermoregulation and energy homeostasis. Pflugers Arch. 2018; 470:761-77. https://doi. org/10.1007/s00424-018-2145-9. PMID:29700598

17. Henshall SM, Afar DE, Hiller J, Horvath LG, Quinn DI, Rasiah KK, Gish K, Willhite D, Kench JG, GardinerGarden M, Stricker PD, Scher HI, Grygiel JJ, et al. Survival analysis of genome-wide gene expression profiles of prostate cancers identifies new prognostic targets of disease relapse. Cancer Res. 2003; 63:4196-203. PMID:12874026

18. Pontén F, Jirström K, Uhlen M. The Human Protein Atlas--a tool for pathology. J Pathol. 2008; 216:387-93. https://doi. org/10.1002/path.2440. PMID:18853439

19. Stein RJ, Santos S, Nagatomi J, Hayashi Y, Minnery BS, Xavier M, Patel AS, Nelson JB, Futrell WJ, Yoshimura N, Chancellor MB, De Miguel F. Cool (TRPM8) and hot (TRPV1) receptors in the bladder and male genital tract. J Urol. 2004; 172:1175-78. https://doi.org/10.1097/01. ju.0000134880.55119.cf. PMID: 15311065

20. Fuessel S, Sickert D, Meye A, Klenk U, Schmidt U, Schmitz M, Rost AK, Weigle B, Kiessling A, Wirth MP. Multiple tumor marker analyses (PSA, hK2, PSCA, trp-p8) in primary prostate cancers using quantitative RT-PCR. Int J Oncol. 2003; 23:221-28. PMID:12792797

21. Bidaux G, Flourakis M, Thebault S, Zholos A, Beck B, Gkika D, Roudbaraki M, Bonnal JL, Mauroy B, Shuba Y, Skryma R, Prevarskaya N. Prostate cell differentiation status determines transient receptor potential melastatin member 8 channel subcellular localization and function. J Clin Invest. 2007; 117:1647-57. https://doi.org/10.1172/ JCI30168. PMID:17510704

22. Alaimo A, Lorenzoni M, Ambrosino P, Bertossi A, Bisio A, Macchia A, Zoni E, Genovesi S, Cambuli F, Foletto V, De Felice D, Soldovieri MV, Mosca I, et al. Calcium cytotoxicity sensitizes prostate cancer cells to standard-ofcare treatments for locally advanced tumors. Cell Death Dis. 2020; 11:1039. https://doi.org/10.1038/s41419-02003256-5. PMID:33288740 
23. Grolez GP, Gkika D. TRPM8 Puts the Chill on Prostate Cancer. Pharmaceuticals (Basel) 2016; 9:44. https://doi. org/10.3390/ph9030044. PMID:27409624

24. Lunardi A, Barbareschi M, Carbone FG, Morelli L, Brunelli M, Fortuna N, Genovesi S, Alaimo A. TRPM8 protein expression in hormone naïve local and lymph node metastatic prostate cancer. Pathologica. 2021; 113:95-101. https://doi.org/10.32074/1591-951X-262. PMID:33955429

25. Xie YH, Chen YX, Fang JY. Comprehensive review of targeted therapy for colorectal cancer. Signal Transduct Target Ther. 2020; 5:22. https://doi.org/10.1038/s41392020-0116-Z. PMID:32296018

26. Dong J, Li B, Lin D, Zhou Q, Huang D. Advances in Targeted Therapy and Immunotherapy for Non-small Cell Lung Cancer Based on Accurate Molecular Typing. Front Pharmacol. 2019; 10:230. https://doi.org/10.3389/ fphar.2019.00230. PMID:30930778

27. Sherkheli MA, Gisselmann G, Vogt-Eisele AK, Doerner JF, Hatt H. Menthol derivative WS-12 selectively activates transient receptor potential melastatin-8 (TRPM8) ion channels. Pak J Pharm Sci. 2008; 21:370-78. PMID:18930858

28. Bödding M, Wissenbach U, Flockerzi V. Characterisation of TRPM8 as a pharmacophore receptor. Cell Calcium. 2007; 42:618-28. https://doi.org/10.1016/j.ceca.2007.03.005. PMID:17517434

29. Duncan D, Stewart F, Frohlich M, Urdal D. Preclinical evaluation of the TRPM8 ion channel agonist D-3263 for benign prostatic hyperplasia. J Urol. 2009; 181:503.

30. González-Muñiz R, Bonache MA, Martín-Escura C, Gómez-Monterrey I. Recent Progress in TRPM8 Modulation: An Update. Int J Mol Sci. 2019; 20:2618. https://doi.org/10.3390/ijms20112618. PMID:31141957

31. Cancer Genome Atlas Research Network. The Molecular Taxonomy of Primary Prostate Cancer. Cell. 2015; 163:1011-25. https://doi.org/10.1016/j.cell.2015.10.025. PMID:26544944

32. Tomlins SA, Laxman B, Varambally S, Cao X, Yu J, Helgeson BE, Cao Q, Prensner JR, Rubin MA, Shah RB, Mehra R, Chinnaiyan AM. Role of the TMPRSS2-ERG gene fusion in prostate cancer. Neoplasia. 2008; 10:177-88. https://doi.org/10.1593/neo.07822. PMID:18283340

33. King JC, Xu J, Wongvipat J, Hieronymus H, Carver BS, Leung DH, Taylor BS, Sander C, Cardiff RD, Couto SS, Gerald WL, Sawyers CL. Cooperativity of TMPRSS2-ERG with PI3-kinase pathway activation in prostate oncogenesis. Nat Genet. 2009; 41:524-26. https://doi.org/10.1038/ ng.371. PMID:19396167
34. Carver BS, Tran J, Gopalan A, Chen Z, Shaikh S, Carracedo A, Alimonti A, Nardella C, Varmeh S, Scardino PT, Cordon-Cardo C, Gerald W, Pandolfi PP. Aberrant ERG expression cooperates with loss of PTEN to promote cancer progression in the prostate. Nat Genet. 2009; 41:619-24. https://doi.org/10.1038/ng.370. PMID:19396168

35. Rosenthal SA, Hu C, Sartor O, Gomella LG, Amin MB, Purdy J, Michalski JM, Garzotto MG, Pervez N, Balogh AG, Rodrigues GB, Souhami L, Reaume MN, et al. Effect of Chemotherapy With Docetaxel With Androgen Suppression and Radiotherapy for Localized High-Risk Prostate Cancer: The Randomized Phase III NRG Oncology RTOG 0521 Trial. J Clin Oncol. 2019; 37:1159-68. https:// doi.org/10.1200/JCO.18.02158. PMID:30860948

36. Grolez GP, Hammadi M, Barras A, Gordienko D, Slomianny C, Völkel P, Angrand PO, Pinault M, Guimaraes C, Potier-Cartereau M, Prevarskaya N, Boukherroub R, Gkika D. Encapsulation of a TRPM8 Agonist, WS12, in Lipid Nanocapsules Potentiates PC3 Prostate Cancer Cell Migration Inhibition through Channel Activation. Sci Rep. 2019; 9:7926. https://doi.org/10.1038/s41598-019-44452-4. PMID:31138874

37. Yu B, Tai HC, Xue W, Lee LJ, Lee RJ. Receptor-targeted nanocarriers for therapeutic delivery to cancer. Mol Membr Biol. 2010; 27:286-98. https://doi.org/10.3109/09687688.2 010.521200. PMID:21028937

38. Yallapu MM, Khan S, Maher DM, Ebeling MC, Sundram V, Chauhan N, Ganju A, Balakrishna S, Gupta BK, Zafar N, Jaggi M, Chauhan SC. Anti-cancer activity of curcumin loaded nanoparticles in prostate cancer. Biomaterials. 2014; 35:8635-48. https://doi.org/10.1016/j. biomaterials.2014.06.040. PMID:25028336

39. Ruigrok EAM, van Vliet N, Dalm SU, de Blois E, van Gent DC, Haeck J, de Ridder C, Stuurman D, Konijnenberg MW, van Weerden WM, de Jong M, Nonnekens J. Extensive preclinical evaluation of lutetium-177-labeled PSMAspecific tracers for prostate cancer radionuclide therapy. Eur J Nucl Med Mol Imaging. 2021; 48:1339-50. https:// doi.org/10.1007/s00259-020-05057-6. PMID:33094433

40. Sadaghiani MS, Sheikhbahaei S, Werner RA, Pienta KJ, Pomper MG, Solnes LB, Gorin MA, Wang NY, Rowe SP. A Systematic Review and Meta-analysis of the Effectiveness and Toxicities of Lutetium-177-labeled Prostate-specific Membrane Antigen-targeted Radioligand Therapy in Metastatic Castration-Resistant Prostate Cancer. Eur Urol. 2021; 80:82-94. https://doi.org/10.1016/j. eururo.2021.03.004. PMID:33840558 